\title{
Music Streaming Characteristics and Consumption Emotion as Determinants of Consumer Satisfaction and Purchase Intention
}

\author{
Chiehwen Ed Hsu \\ Institute of International Management, National Cheng Kung University, Taiwan \\ E-mail: cedhsu@mail.ncku.edu.tw \\ Yeshwant S. Raj* \\ Institute of International Management, National Cheng Kung University, Taiwan \\ E-mail: yeshwantraj.s@gmail.com \\ Bob Sandy \\ Institute of International Management, National Cheng Kung University, Taiwan \\ E-mail: bob.sandy199@gmail.com
}

\begin{abstract}
The present study analyzes consumers perceptions of music streaming and how such perceptions might influence customers brand loyalty and purchase intent. The competitive advantages of music streaming, widely known for its cost-saving measures, ease of use, and worldwide accessibility, are carefully reviewed herein. The S-O-R Theory commonly employed in psychology studies is applied in this study to explain the relationship between the product characteristics of streaming music (e.g., price, content quality, functionality, convenience, and design) and consumer behavior as seen by consumption emotions. This relationship is viewed as either positive or negative in consumer satisfaction and purchase intention. The data were collected through an online web-based survey questionnaire. One thousand seven (1007) subjects from Indonesia completed the survey. The Structured Equation Modeling (SEM) was used to examine the relationship among product attributes, consumer satisfaction, and purchase intention. Our study findings revealed a strong association between emotion and particular product characteristics, whereby a positive emotion exists across all product characteristics in music streaming services. The design variable is the most popular function of all music streaming services product attributes. Our findings suggest that either positive or negative emotions may predict the functionality
\end{abstract}


constructions in comparison with previous research results. On the other hand, the findings of the present study suggest that only positive emotions can influence the satisfaction level of consumers and, in turn, affect the consumers purchasing intent

Keywords: Music streaming, S-O-R theory, Product attributes, Consumption emotion, Consumer satisfaction, Purchase intention, Indonesia

\section{INTRODUCTION}

Tune entertainment services have been steadily evolving over recent years. Users are now facilitated with the utility to take notes of radio tunes, to save songs on a large capacity storage medium (e.g., Compact Disc (CD), Vinyl Disc, or Cassette Tapes, or a thumb drive, and so on.), perform digital sharing (e.g., pc files saved in both MP3, FLAC, or WAV, and so forth) and even to optimize tune streaming offerings. Music streaming services enable the customers to track through the Internet without having to worry about the copyright of the tunes on the physical media or virtual files (Wlömert \& Papies, 2016).

The transmission mechanism of tune streaming is by way of private company service, which provides users with access to a much wider collection of songs than traditionally accessible. Such collection may be saved to a tracking database that the streaming service provider made available, otherwise known as the Internet "Cloud". The cloud is an internet carrier of music files exchange network server where customers can keep their information in audio and video form and access them on demand from anywhere and every time the need arises) (Doerr et al., 2010). Popular cloud services for track streaming include 1) realtime streaming radio services such as Pandora and Accuradio.com, and 2) on-demand streaming media such as Spotify, Deezer, and Apple Music, and so forth (Kim et al., 2017). The benefits or the privilege of on-call for a song-stream club potentially make it the most popular/famous tune streaming service on the market today.

The song streaming offerings started to gain popularity in 2005 and continued sustained development through the ensuing years. There appears to be a major increase in the use of tune streaming services by hobbyists due to growth in the number of individuals who are willing and able to pay for song streaming club services (top class users). Such growth in the use of streaming services is evidenced by the current use of Spotify, 5 percent, of which accelerated from 112 million customers in 2017 to 176 million in 2018 globally. The effect of increasing music streaming services strongly shows that consumers considerably prefer this mode of tune delivery physical media which they view as inconvenient, lacking in choice, and high in cost. 
As regards this subscription business model, music streamers access from Premier consumers is generated through either (1) annual membership fees and (2) free consumer advertising (Wlömert \& Papies, 2016). It is regarded as a Freemium business case where both the 'reasonable' and 'premium' Freemium hybrid concept is used (Doerr et al., 2010). The freemium business model encompasses both limited access to free users and full consumer awareness (Aguiar, 2017). For free users, this offers an advertising subscription service, where profits are mainly generated from ad sales rather than users directly charging, is reduced usability. The customers can use exclusive features that are impractical for users for free: enjoy listening to the same songs again or choosing songs of their preference (Aguiar, 2017; Doerr et al., 2010).

Several studies of consumer behavior in the music streaming services were conducted by Doerr and colleagues (Doerr et al., 2010) and Jihwan Kim and colleagues (Kim et al., 2017) in the past. These studies mainly focused on finding the Willingness to Pay (WTP) and identifying the most important attributes of music streaming services from consumers in different regions such as Germany, the US, and South Korea. The study found that people in Germany considered price, contract duration, audio quality, and music access as the most important attributes of the music streaming services they use. The study conducted by Jiwhan Kim and colleagues (Kim et al., 2017) focuses on the comparison between the music streaming markets in both the US and South Korea. Their study found that the most important attributes of music streaming services for users in the US ranked by order of importance are namely: streaming mode, advertisement, offline usage, and exclusive contents, where the first two attributes are considered more important than the rest. Surprisingly, sharing the same similarity of the results of preference, users from both the US and South Korea see the exclusive content (i.e., content that made specifically for users who use the music streaming services) as the least important attribute of music streaming due to unattractive offer from music streaming service providers at that time.

Since previous studies reported in the literature of music streaming had been conducted with a primary focus in the area of consumers' WTP of music streaming services, this study adopted different approaches by looking at consumers' perceptions of music streaming attributes. Consumption emotion, which refers to the feeling that occurred during or after consuming a product or service that is classified as a positive emotion and negative emotion, will also be used herein as a determinant to understand how the product attributes of the music streaming industry may increase consumer satisfaction which may, in turn, leads to purchase intention of music streaming services. 
Similar to most of the studies in marketing and consumer behavior fields that widely adapted theories from the psychology field, the S-O-R theory also has been applied widely in many consumer behavior studies, including e-commerce (Jiang et al., 2010; Kim et al., 2013; Patanasiri \& Krairit, 2019; Wu et al., 2008), retail (Chang et al., 2011; Thang \& Tan, 2003), restaurants (Jang \& Namkung, 2009; Namkung \& Jang, 2010), social media (Carlson et al., 2018; Grace et al., 2015), high-technology devices (Lee et al., 2011), tourism (Lee, 2014), and Internet website (Hsu et al., 2012; Jiang et al., 2010). The objectives of this study are formulated to investigate consumer behavior specifically in the market of Indonesia.

1.The first objective is to further understand consumers' perception of music streaming attributes in Indonesia.

2. The second objective is to investigate how consumers' perception of music streaming attributes might influence consumer satisfaction and purchase intention through consumption emotion in Indonesia.

3.The third objective is to find out what is the most important product attributes of music streaming that influence consumers' decision to use music streaming services as their music consumption platform in Indonesia.

\section{THEORETICAL BACKGROUND}

\section{S-O-R Theory}

The S-O-R theory, also known as Mehrabian-Russell (M-R) model, was originally developed in the environmental psychology field by Mehrabian and Russell in 1974 (Lee, 2014). This M-R model is an extension of the S-R theory that was introduced decades earlier by Woodworth and Schlosberg (1954) from the behavioral psychology field (Royce, 1963; Shulley \& Shake, 2016). Experimental psychologists used the original theory to explain animal behavior responding to different stimuli in a laboratory experiment (Lee, 2014). Shortly after the theory was published and revealed to the world, this first version of the S-O-R Theory received much criticism because it was being used to explain complex human emotion in a simplistic framework or was allegedly oversimplified (Shulley \& Shake., 2016; White, 1993). Woodworth later expanded with an intermediary variable between Stimulus and Response and explained that these intermediary variables could be a motivation, a purpose, or a tendency to respond to the stimuli. Contrary to the earlier form of the S-O-R Theory, Mehrabian and Russell (1974) argued that different environmental stimuli trigger human emotion. Based on the M-R model of the S-O-R theory, a human's feeling towards the environment is influenced by his or her perceptions of both the physical and social environment (Lee, 2014). The S-O-R theory is not only 
popular in the psychology field, but it is also widely employed in consumer behavior studies (Chang et al., 2011; Fiore \& Kim, 2007). In terms of consumer behavior, Cho et al. (2018) explained that different stimuli like product attributes, design, features, and store atmosphere could influence the transformation of consumers' internal conditions or emotions into consumers 'responses toward the stimuli. Bagozzi (1986) adds that under the S-O-R theory, an organization works as a cognitive process that connects the environmental stimuli and reactions of a person. The S-O-R theory was created subsequently to better explain the process of consumer decisions at the level of individuals, groups and organizations (Patanasiri \& Krairit, 2019).

In terms of the decision-making process, the stimulus can be identified as an ongoing decision by consumers (Chang \& Jai, 2015). According to Bagozzi (1986), the stimulus could be anything outside of someone that consists of both combined positioning variables and external environmental factors. In the S-O-R model, the stimulus is used to influence consumer perception (Alexander \& Cano, 2019). A stimulus can be identified as two categories: both object and environmental stimuli (Arora, 1982; Wong, 2020). Object stimuli consist of product attributes, the time consumption of the product, and the complicity of the product. Meanwhile, the environmental stimulus is derived from the surrounding individuals or the store atmosphere (Arora, 1982). In terms of technology products, stimuli contribute to the consumer buying process where consumers' understanding of product characteristics (e.g., model, performance, etc.) goes along with his or her experience in purchasing and consumption (Lee et al., 2011). Product attributes can be recognized as either tangible or intangible product features, such as price, design, function, brand, benefits, etc. These features all contribute to the success of product marketing (Keightley, 2010; Meyers-Levy \& Tybout, 1989; Park et al., 2018). In retailer studies, a stimulus can be categorized as either a physical or social environment (Jiang et al., 2010; Patanasiri \& Krairit, 2019). A stimulus may also be manifested in many forms, such as the appearance of products, the atmosphere of the store, or the salesperson's availability (Jacoby, 2002). The environment stimulus is popular and widely used in the examination of both physical and online retail studies to examine how environmental stimulus influences consumer behavior in retail settings. This study applied product attributes as an object stimulus, including price, content quality, convenience, functionality, and design. This study refers to the literature from technology product studies such as smartphones, tablets, personal computers, smartwatches, wearable devices, ecommerce, etc., for describing the product characteristics of music streaming. 
Organism in the S-O-R theory can also be perceived as a human cognitive process. The cognitive process refers to "everything that goes inside consumers mind concerning the acquisition, processing, retention, and retrieval of information" (Islam \& Rahman, 2017). In the S-O-R model developed by Mehrabian and Russell (1974), organism refers to three emotional conditions: namely pleasure, arousal, and dominance, or known collectively as "PAD". According to Richins (2013), the PAD measurement developed by Mehrabian and Russell (1974) was not designed to measure the entire aspects of consumer emotional condition but only consumers 'emotional responses toward the environmental stimulus, also known as "atmospheric". The PAD scale may effectively measure consumers' feelings towards the store environment but not the consumption experience (Richins, 2013; Zhu et al., 2012). This point of view is recognized by Mehrabian and Russell (1974). They posited that the PAD measurement may be best employed to capture individuals" "emotional response" towards the environment but might not effectively capture individuals 'experience. Therefore, this study will apply the Differential Emotions Scales (DES) proposed by Izard (1977) to measure consumer consumption experience in music streaming.

Responses in the S-O-R theory are referred to as the outcomes of the process of stimulus-organism-response, whether they result from either approaching or avoiding the stimulus (Vinish et al., 2020). The responses to the stimuli can be classified as either external responses or internal responses (Jacoby, 2002). The internal response is the emotional response towards the previous experience that resulted in feelings of satisfaction or dissatisfaction. Meanwhile, the external response could be a behavior of consumers toward the previous experience, such as purchasing or not purchasing. The positive environmental stimulus will prompt the approach behavior, while the negative environmental stimulus will encourage the avoidance behavior (Mehrabian \& Russell, 1974). The approaching behavior is a positive response to the environmental stimulus where it refers to activities of the person to either remain, explore, give attention, or get together with other parties in the same environment, while the avoidance behavior is a negative response to the environment and refers to a person's behavior who tries to avoid, escape, or be indifferent from his or her current environment and also tries to block all forms of communication from other parties (Francioni et al., 2018; Lee, 2014). According to Jacoby (2002), the response in the S-O-R theory can be defined in many different forms, and the outcome of it can be extended from either being aware or unaware, or either inside (unseen) or outside (recognizable) of humans. Bagozzi (1986) further posited that responses in the consumer behavior study are reactions of consumers to the outcomes of 
the process in the S-O-R process, and they can be differentiated as behavioral reactions or psychological reactions.

\section{Consumption Emotion}

Darwin (1979) argued in his book that emotions play an important role in increasing an organism's chance to survive in nature. Bagozzi et al. (1999) defined emotion as a mental condition of readiness that emerges from subjective evaluations of occasions or musings. Emotion has been studied as an important subject area in Consumer Behavior studies Troiville et al. (2019). Most studies about consumer emotion in the consumer behavior field were originally developed or borrowed from the psychology literature (Richins, 2013). The earlier studies about emotion in the Consumer Behavior field were mainly focused on advertisements, and it has been applied to other subjects in the ensuing (Richins, 2013). Literature about consumer consumption experience has explored the role of emotion in many different subjects such as products (Kim et al., 2016; Mehrabian \& Russell, 1974; Mehrabian \& Wixen, 1986), services, possessions (Watkins \& Molesworth, 2012), and different consumption situations (de Hooge, 2014; Sabiote Ortiz et al., 2017). These studies found that emotion plays an important role in influencing consumer consumption behavior. Consumer consumption experience and its reaction can be defined by measuring consumer emotion during or after the time consumers use the product or services (Babin et al., 1998). To measure emotion in terms of consumer consumption, Izard (1977) developed a set of Differential Emotions Scales (DES) measurements. The measurement set of emotions proposed by Izard (1977) consists of 10 different emotion dimensions, which are named "interest, joy, surprise, sadness, anger, disgust, contempt, fear, shame, and guilt. This study will divide the said set of emotions into two parts (both positive and negative) due to each emotion's different effects and influences. This separation is based on the study conducted by Jang and Namkung (2009) to measure consumer's emotions in the restaurant setting. The study "individual affective experiences" found that positive emotion and negative emotion are two "independent unipolar" dimensions that represent human emotion related to individual experience (Bradburn, 1969; Jörling et al., 2020). This is in line with the study's finding conducted by Westbrook and Oliver (1991), saying that emotion in consumption experience has two dimensions: positive emotion and negative emotion, instead of one "bipolar" dimension. Westbrook and Oliver (1991) argued that the complexity of consumption experience could not be captured by using a combined set of emotion measurements or usually called the "bipolar" dimension. Therefore, Han and Back (2007) suggested using "the valence of consumption 
emotion" to fill the gap and limit the combined set of emotion measurements. Several studies statistically proved that positive and negative emotion has an important role in explaining the feeling in "consumption emotion" by using factor analysis (Morimura et al., 2014; Zhu et al., 2012). More importantly, consumption emotion is also recognized in consumer behavior study of its powerful ability to predict consumption behavior (Han \& Back, 2007). Numerous consumer behavior studies have explored the relationship between consumption emotion and several aspects of consumer behavior such as preference, evaluation, recommendation, and purchase intention (Han \& Back, 2007; Reynoso, 2010; Zhu et al., 2012).

\section{Consumer Satisfaction}

According to Reynoso (2010), consumer satisfaction can be defined as consumers' psychological state when the result of the consumption experience is better than the expectation of prior consumption experience of consumers. Consumer satisfaction can also be defined as the aftermath or ongoing process of consumers' evaluation by comparing consumer expectation, prior experience, and current situation of using the product or services. The outcome of this process can be classified as either satisfied, neutral, or unsatisfied (Anderson, 1973; Herrera \& Blanco, 2011). Satisfaction in the consumer perspective is usually judged by comparing the level, quality, and other features of the purchased product or services in use, to the criteria set forth by the consumers themselves personally or generally (Westbrook \& Oliver, 1991). Sometimes, consumers also compare the costs and the benefits of the product for deciding whether they are satisfied or unsatisfied with the product purchase (Churchill Jr \& Surprenant, 1982). The recognition of consumer satisfaction as an important factor in both marketing and consumer behavior studies has prompted the growth of the studies in academic research in recent years (Bearden \& Teel, 1983). Whether in theory or in practice, marketing in the modern era considers consumer satisfaction as an essential concept to make sure that consumers feel satisfied, and they will give more profits to the company as a re-purchasing result. Consumer satisfaction is important for marketers because it can be used to determine "consumer loyalty", "repeat sales", "positive word-of-mouth", and a rise in "company market share and profitability" (Annaraud \& Berezina, 2020; Bearden \& Teel, 1983; Bhattacherjee, 2001). Based on consumers 'perspectives, consumer satisfaction is also important because it can be used as an indicator by companies to improve the quality of the product and services in order to meet consumers 'expectations. "Attribute Satisfaction"

is one of the indicators that is being used to measure consumer satisfaction and is thereby judged based on the product attribute performance (Flores \& Vasquez-Parraga, 2015). 
Studies of consumer satisfaction in e-commerce reported that consumer satisfaction is a key factor that leads to re-purchase intention, and as such, it helps a company to build and maintain consumers 'brand loyalty (Bhattacherjee, 2001; Evanschitzky et al., 2004; Srivastava \& Rai, 2013).

\section{Purchase Intention}

According to Ajzen (2020), consumer purchase intention is considered as an emotional intensity or desire to make a purchase, and it will likely result in the actual purchase action in a short time. Purchase intention is one of the dimensions of behavioral intention. The purchase intention variable is recommended to be used to predict consumer behavior patterns because it reflects the actual behavior of consumers (Ajzen \& Fishbein, 1980; Lemon \& Verhoef, 2016). Alalwan et al. (2017) posit that purchase intention could increase the probability of consumers purchasing products or services. They further contended that consumers probably buy something because of "constraints" rather than their "real preferences"; therefore, the intentional measurement will be more suitable than behavioral measurement in understanding consumers' 'minds (Bilgili \& Ozkul, 2015).

Belk (2015) classified purchase intention into three types: unplanned purchase, halfplanned purchase, and planned purchase. Unplanned purchase intention can be perceived as consumer decisions about purchasing specific products and brands on site. Half-planned purchase intention is contingent upon a decision of a particular brand, a condition when consumers already know what products to buy but still not decided on which brand to purchase. Planned purchase intention is when a consumer is sure about which product and what brand to purchase. In terms of online purchase, consumer intention can determine or predict when the consumer will make an actual purchase through either the Internet (Salisbury et al., 2001) or other retailers with a physical storefront. Pavlou (2003) added that consumers are eager to participate in online transactions in online purchase intention. Consumer purchase intention is important because it is indicative of the actual behavior of consumer purchasing (Bai et al., 2008). Purchase intention has also been applied in several studies that use the S-O-R theory as an underlying Theoretical Framework (Jang \& Namkung, 2009; Jiang et al., 2010; Lee \& Yun, 2015; Wu et al., 2013).

\section{Hypotheses Development}

\section{Price towards emotion}

Public frustration arises anywhere they perceive injustice and may be related to the perceived excessive costs for goods or services. This can contribute to a negative feeling 
which is a natural response to unequal treatment (Demangeot \& Broderick, 2010; Rose, 2013). A "deception," "pain" or "outrage" (Austin et al., 1980) may be a negative emotion, or they may both appear at once. Contrary to the previous case, responses like optimistic emotion, which are either "love" or "surprise," may arise when customers find that the offer is fair and take it. "Deception," "pain" or "outrage" (Austin et al., 1980) may be negative emotions, which may appear at once. Contrary to the previous case, responses like "positive emotion", which is either "joy" or "surprise," may occur when customers view the prices as fair and therefore may contribute to a sense of gratification (Yoo \& Kim, 2014). We suggest the following hypothesis based on the discussion in this study:

H1a. Price has a positive effect on positive emotion.

H1b. Price has a negative effect on negative emotion.

\section{Content quality towards emotion}

According to Westbrook and Oliver (1991), emotion (instead of satisfaction) is usually judged by comparing the level of product performance, product quality, and any other objective standards set by the consumer with other products. Zhu et al. (2012) argued that the satisfaction feeling arises from emotional evaluation after product consumption. In response to this viewpoint, this study further proposes:

H2a. Content quality has a positive effect on positive emotion.

H2b. Content quality has a negative effect on negative emotions.

\section{Functionality towards emotion}

Research suggests that the look and feel play an important role in a purchase decision. For instance, according to the study conducted by Chitturi et al. (2007), when given an option to choose between a product with a more aesthetically appearance and a product with functionality advantages, consumers tend to choose the former with a better look and feels. The finding suggests that although a sense of guilt may occur, a consumer will choose a product that has an aesthetical appeal over the one that offers more functionality. To reduce the negative emotion of guilt, companies are advised highly to focus on the product design and seek to add more features of functionality to give the advantage of a better look and feel to their products. Chitturi et al. (2007) also found that consumers 'emotions at the time of purchase play a critical role in consumers' decision whether to buy a product with either a good design or a product with the best functions. Therefore, the present study proposes the following hypotheses: 
H3a. Functionality has a positive effect on positive emotions.

H3b. Functionality has a negative effect on negative emotions.

\section{Convenience towards emotion}

Consumers concerned about time efficiency will feel mentally pressured when the time needed to get the benefits of product consumption is high (Jennings et al., 2017). As such, it may, in turn, lead to a negative perception of the convenience of product consumption, thereby resulting in negative emotion (Hui \& Tse, 1996; Morimura et al., 2014). Nah et al. (2011) argued that positive perceptions of technology-related products are achieved when consumers can spend less time and physical and emotional attention in using them. Therefore, this study proposes:

H4a. Convenience has a positive effect on positive emotion.

H4b. Convenience has a negative effect on negative emotions.

\section{Design towards emotion}

Several studies on user interface effects on user behavior suggested that emotion plays an important role in influencing user behavior towards a Website, based on its design (Deng \& Poole, 2010; Hassenzahl \& Tractinsky, 2006). This is in line with Bloch's finding (1995), whereby he suggested that product design may trigger consumer emotional response to the aesthetical aspect of the product. Based on the study findings, the present study proposes:

H5a. The design has a positive effect on positive emotions.

H5b. The design has a negative effect on negative emotions.

\section{Emotion towards consumer satisfaction}

The influence of emotion on consumer satisfaction and behavioral intention happened either before, during, or after consumption (Barsky \& Nash, 2002; Wong et al., (2020); Reynoso, 2010). This is in line with Zhu et al., (2012) argument, suggesting that consumer satisfaction is the result of the consumer evaluation based on the emotion either during or after the product consumption. This process is widely known and studied in contemporary literature of marketing and consumer behavior. Therefore, the present study proposes: 
H6a. Consumer satisfaction has a positive effect on purchase intention.

H6b. Consumer satisfaction emotion has a negative effect on purchase intention.

\section{Emotion towards purchase intention}

In the Mehrabian-Russell (M-R) model, they posited that consumers' behavioral response to the stimulus, such as purchase intention, is influenced by consumer emotion (Ha \& Lennon, 2010; Wu et al., 2008). Several research studies have shown that emotion influences consumer "behavioral response" (Jang \& Namkung, 2009; Kim \& Lennon, 2013; Kim et al., 2013; Namkung \& Jang, 2010; Yoo \& Kim, 2014). As such, the present study proposes:

H7a. Consumer positive emotion has a positive effect on purchase intention.

H7b. Consumer negative emotion has a negative effect on purchase intention.

\section{Consumer satisfaction towards purchase intention}

According to Lemon and Verhoef (2016), consumers 'purchase intention is highly influenced by consumer satisfaction with a specific product. The relationship between consumer satisfaction and purchase intention has been verified in previous studies in several industries, such as in Healthcare (Taylor \& Baker, 1994), m-commerce (Malik, 2012), mobile app (Hsu \& Lin, 2016), and e-commerce (Zhang et al., 2015). Accordingly, the present study proposes:

H8. Consumer satisfaction has a positive effect on purchase intention.

\section{Sampling Plans}

\section{METHODOLOGY}

This study uses an online survey questionnaire provided by Google form. The questionnaire items, less the control variable, are designed using a 5-point Likert Scale ranging from 1 (strongly disagree) to 5 (strongly agree). The target population of the present study is the online community of Indonesian audio enthusiasts in social media known as the Audio Kere Hore (AKH) group, with members counts of about sixty-six thousand people in the group as of 2019. Questionnaire items are adopted from several previous pieces of literature like Price (Adopted with modification from Oyedele \& Simpson, 2018), Content quality (Adopted with modification from Yang \& Lee, 2018), Functionality (Adopted with modification from Park et al., 2018; Yang \& Lee, 2018), Convenience (Adopted with modification from Oyedele \& Simpson, 2018), Design 
(Adopted with modification from Li \& Yeh, 2010), Emotion (Adopted with modification from Jang \& Namkung, 2009), Consumer satisfaction (Adopted with modification from Gan \& Wang, 2017), Purchase intention (Adopted with modification from Wagner et al., 2014). For the back-translation, the questionnaire items were translated to Indonesian from the English version since the target respondents of this study are Indonesian and translated back to English to make sure the questionnaire items did not lose their original meaning.

Figure 1 SEM Result of the Research Framework

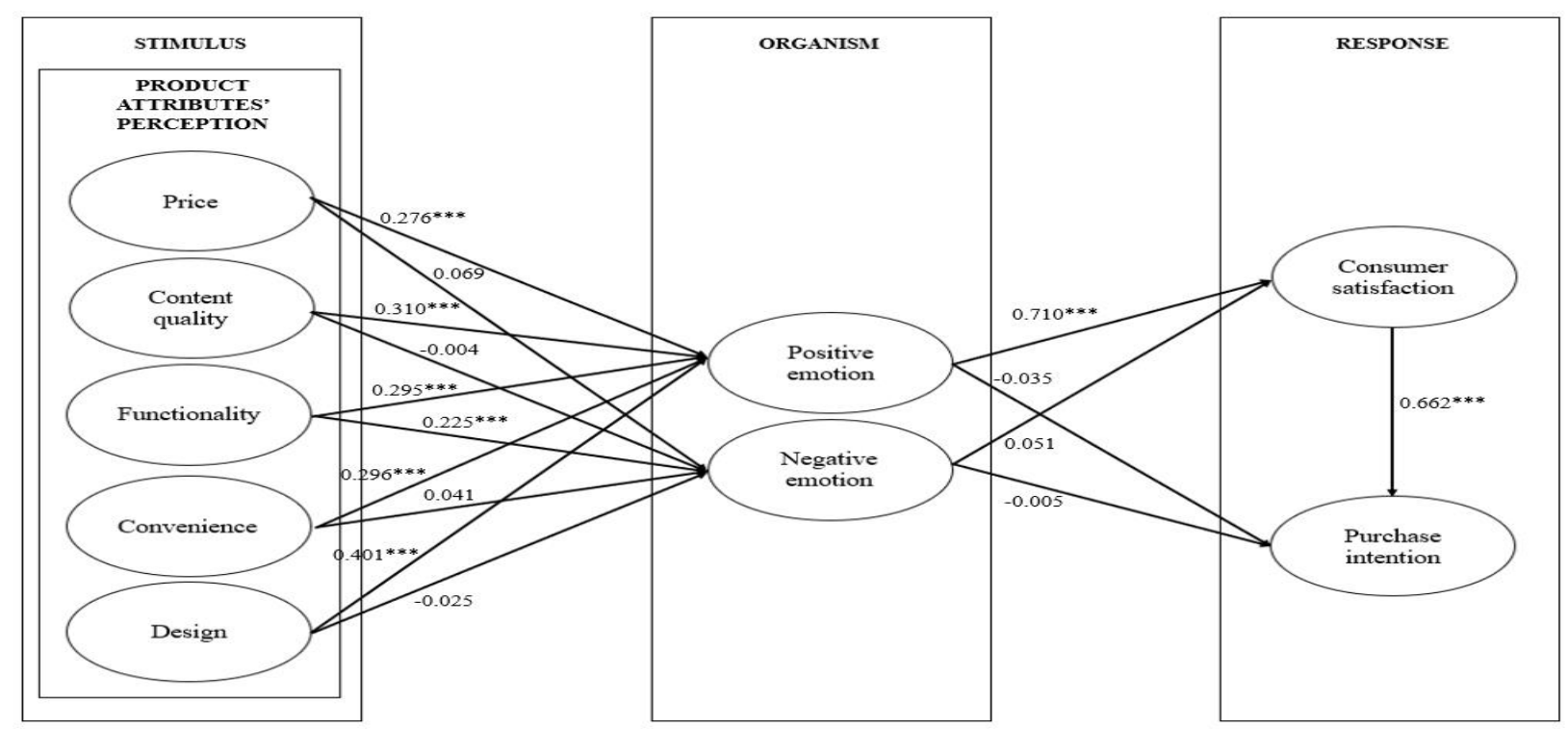

\section{Statistical Results}

Most of the respondents are male. They make up some $99.3 \%$ of the total number of respondents, aged between 18-24 years old (56.1\%). The data also show that most of the respondents are students (31.3\%) and full-time employees (31.1\%) and have been using the music streaming services for 1 to 3 years $(28.8 \%)$. The result of standardized factor loading of most items met the criteria and is satisfactory, where the standardized factor loading of all items ranges from 0.634 to 0.911 . Overall, the result of the CFA produces a good model fit where all the indicators meet the criteria $\left(x^{2}(341)=953.436, x^{2} / \mathrm{df}=2.796\right.$, $\mathrm{p}<0.001, \mathrm{GFI}=0.937, \mathrm{AGFI}=0.920, \mathrm{NFI}=0.937, \mathrm{CFI}=0.958, \mathrm{RMSEA}=0.042)$. Results meet the criteria except for $x^{2} / \mathrm{df}$ (6.166). According to Hair et al. (2014), such as in this case, the CMIN/df cannot be used to measure model fit in a study with a sample size larger than 750 .

\section{Pilot Study}


Before doing the actual survey, a pilot test was conducted on a sample of 50 respondents. The purpose of the pilot test was to make sure that participants understand the meaning of the questionnaire items since the target participants are Indonesian and the questionnaire items were translated from English to Indonesian. The pilot test was conducted by gathering 50 Indonesian participants outside the target population of this study. Most of the participants in the pilot test were students, office workers, and friends of authors from undergraduate schools. The reliability test was conducted for this pilot test to anticipate and minimize errors in the data analysis of the actual survey. Some items were deleted for not meeting the criteria of the reliability test, such as low Cronbach's alpha value.

\section{RESULTS}

According to Hair et al. (2014), the ideal number of standardized factor loading should be greater than 0.70 , but the value of 0.50 is still accepted. As shown in Table 1, the result of standardized factor loading of most of the items met the criteria and such as is satisfactory where the standardized factor loading of all items range from 0.634 to 0.911 . CQ1 and F1 were deleted because both items standardized factor loading does not meet the criteria. It also indicates that these two items did not reflect its construct. The result of Construct Reliability (CR) is satisfactory where the results of all items are higher than 0.70 , which meets the criteria proposed by Hair et al. (2014). It indicates that internal consistency exists among all items.

\section{Hypothesis 1.}

The hypothesis is supported with $\beta=0.276^{* * *}$, $\mathrm{t}$-value $=7.318$, and $\mathrm{p}$-value $=0.000$. It indicates that price has a positive relationship with positive emotion. Positive emotion will occur when consumers perceive the price of products or services as reasonable. In contrast, hypothesis $1 \mathrm{~b}$ with $\beta$ is equal to 0.069 , $\mathrm{t}$ value is equal to 1.852 , and the $\mathrm{p}$-value is equal to 0.064 , is not supported. It indicates that price has no influence on consumer's negative emotions.

\section{Hypothesis 2.}

Hypothesis $2 \mathrm{a}$ is supported where $\beta$ is equal to $0.310^{* * *}$, the $\mathrm{t}$-value is equal to 8.031 , and the $\mathrm{p}$-value is equal to 0.000 . It indicates that content quality has a positive relationship with positive emotion. Consumers will feel satisfied as a result of the emotional evaluation of product quality after the consumption process. Hypothesis $2 \mathrm{~b}$ with $\beta$ is equal to -0.004 , 
$\mathrm{t}$ value is equal to -0.107 , and the $\mathrm{p}$-value is equal to 0.915 , is not supported and indicates that content quality has no influence on negative emotion.

\section{Hypothesis 3.}

Both hypothesis 3a $\left(\beta=0.295^{* * *}\right.$, t-value $=6.914$, and $\mathrm{p}$-value $\left.=0.000\right)$ and hypothesis $3 \mathrm{~b}\left(\beta=0.295^{* * *}\right.$, $\mathrm{t}$-value $=6.914$, and $\mathrm{p}$-value $\left.=0.000\right)$ are supported. It indicates that functionality has influence on both positive emotion and negative emotion. Companies are expected to provide more functionality of its product to reduce the negative emotion and increase the positive emotion.

\section{Hypothesis 4.}

Hypothesis $4 \mathrm{a}$ is supported where $\beta$ is equal to $0.296^{* * *}, \mathrm{t}$ value is equal to 8.256 , and the $\mathrm{p}$-value is equal to 0.000 . It indicates that convenience influences positive emotions. Contrary to the previous hypothesis, the hypothesis $4 \mathrm{~b}(\beta=0.041$, $\mathrm{t}$-value $=$ 1.153 , and $p$-value $=0.249$ ) is not supported. It indicates that convenience does not influence negative emotions.

\section{Hypothesis 5.}

The hypothesis $5 \mathrm{a}$ is supported where $\beta$ is equal to $0.401 * * *, \mathrm{t}$ value is equal to 10.357 , and the $\mathrm{p}$-value is equal to 0.000 , and the hypothesis $5 \mathrm{~b}$ with $\beta$ is equal to -0.025 , $\mathrm{t}$ value is equal to -0.687 , and the $\mathrm{p}$-value is equal to 0.492 , is not supported. It indicates that the user interface influences user emotion to determine user behavior. This study also suggests that design has a positive influence on positive emotion but no influence on negative emotion.

\section{Hypothesis 6.}

The hypothesis $6 \mathrm{a}$ is supported where $\beta$ is equal to $0.710^{* * *}, \mathrm{t}$ value is equal to 14.571 , and $\mathrm{p}$-value is equal to 0.000 , and the hypothesis $6 \mathrm{~b}(\beta=-0.035$, $\mathrm{t}$-value $=-0.610$, and $\mathrm{p}$-value $=0.542$ ) is not supported. It indicates that the satisfaction feeling is the result of emotional evaluation during the consumption process. The result of this finding also shows that consumer satisfaction is affected by positive emotion, and positive emotion has no influence on purchase intention. 


\section{Hypothesis 7.}

Both hypotheses $7 \mathrm{a}(\beta=0.051, \mathrm{t}$-value $=1.634$, and $\mathrm{p}$-value $=0.102)$ and $7 \mathrm{~b}(\beta=-$ 0.005 , t-value $=-0.160$, and $\mathrm{p}$-value $=0.873)$ are not supported. It indicates that negative emotion has no influence on either consumer satisfaction or purchase intention.

\section{Hypothesis 8.}

Hypothesis 8 with $\beta$ is equal to $0.662 * * *$, $\mathrm{t}$ value is equal to 11.172 , and the $\mathrm{p}$-value is equal to 0.000 is supported. It indicates that consumer who feels satisfied tend to have higher intention to pay for the subscription fee of music streaming. Table 1 explains the descriptive statistical analysis and the validity testing using SEM.

Table 1 Descriptive Statistical Analysis of All Variables and Reliability Check

\begin{tabular}{|c|c|c|c|c|c|c|c|}
\hline variable & $\begin{array}{l}\text { questionnaire items } \\
\qquad \mathrm{N}=1,007\end{array}$ & item & mean & $\begin{array}{c}\text { STD } \\
\text { deviation }\end{array}$ & $\begin{array}{l}\text { loading } \\
\geq \mathbf{0 . 7 0}\end{array}$ & $\begin{array}{c}\text { CR } \\
\geq \mathbf{0 . 7 0}\end{array}$ & $\begin{array}{l}\text { AVE } \\
\geq 0.50\end{array}$ \\
\hline \multirow{3}{*}{ Price } & $\begin{array}{l}\text { I feel that the subscription cost of } \\
\text { music streaming services is not } \\
\text { expensive compared to alternative } \\
\text { services such as buying CDs or } \\
\text { digital files from Internet. }\end{array}$ & P1 & 3.89 & 1.011 & 0.747 & \multirow{3}{*}{0.780} & \multirow{3}{*}{0.542} \\
\hline & $\begin{array}{l}\text { I feel that using music streaming } \\
\text { services offer significant cost } \\
\text { savings compared to alternative } \\
\text { services such as buying CDs or } \\
\text { digital files from Internet. }\end{array}$ & $\mathrm{P} 2$ & 3.92 & 1.004 & 0.765 & & \\
\hline & $\begin{array}{l}\text { I feel that using music streaming } \\
\text { services is cost effective compared } \\
\text { to buying CDs or digital files from } \\
\text { Internet. }\end{array}$ & P3 & 3.90 & 1.063 & 0.695 & & \\
\hline \multirow{3}{*}{$\begin{array}{l}\text { Content } \\
\text { Quality }\end{array}$} & $\begin{array}{l}\text { Music streaming services provide } \\
\text { up-to-date music. }\end{array}$ & CQ1 & 4.43 & 0.876 & Deleted & \multirow{3}{*}{0.744} & \multirow{3}{*}{0.595} \\
\hline & $\begin{array}{l}\text { The audio quality of the songs } \\
\text { provided by music streaming service } \\
\text { providers is good. }\end{array}$ & CQ2 & 3.86 & 0.926 & 0.686 & & \\
\hline & $\begin{array}{l}\text { The audio quality of the songs } \\
\text { provided by music streaming service } \\
\text { providers suits my preference. }\end{array}$ & CQ3 & 3.93 & 0.882 & 0.848 & & \\
\hline
\end{tabular}


Contemporary Management Research 173

Table 1 Descriptive Statistical Analysis of All Variables and Reliability Check (con.)

\begin{tabular}{|c|c|c|c|c|c|c|c|}
\hline \multirow{3}{*}{ Functionality } & $\begin{array}{l}\text { The performance of features on } \\
\text { music streaming services is stable. }\end{array}$ & $\mathrm{F} 1$ & 3.71 & 0.927 & Deleted & \multirow{3}{*}{0.714} & \multirow{3}{*}{0.555} \\
\hline & $\begin{array}{l}\text { Using music streaming services is } \\
\text { good and easy to access. }\end{array}$ & $\mathrm{F} 2$ & 4.42 & 0.792 & 0.725 & & \\
\hline & $\begin{array}{l}\text { Music streaming services are } \\
\text { compatible with my other devices, } \\
\text { such as PC, tablet, smartphone, etc. }\end{array}$ & F3 & 4.54 & 0.784 & 0.765 & & \\
\hline \multirow{5}{*}{ Convenience } & $\begin{array}{l}\text { Music streaming services allow me } \\
\text { to listen to whatever I want } \\
\text { (Podcast, music, and radio) } \\
\text { whenever I choose. }\end{array}$ & $\mathrm{C} 1$ & 4.16 & 1.003 & 0.757 & \multirow{5}{*}{0.875} & \multirow{5}{*}{0.583} \\
\hline & $\begin{array}{l}\text { Music streaming services allow me } \\
\text { to listen to whatever I want } \\
\text { (Podcast, music, and radio) at a } \\
\text { convenient time. }\end{array}$ & $\mathrm{C} 2$ & 4.29 & 0.858 & 0.798 & & \\
\hline & $\begin{array}{l}\text { I value the ability of music } \\
\text { streaming services to listen to } \\
\text { whatever I want (Podcast, music, } \\
\text { and radio) while away from home. }\end{array}$ & $\mathrm{C} 3$ & 4.21 & 0.877 & 0.750 & & \\
\hline & $\begin{array}{l}\text { I like the ability to use music } \\
\text { streaming services to listen to } \\
\text { whatever I want (Podcast, music, } \\
\text { and radio) on multiple devices (PC, } \\
\text { tablet, smartphone, etc.). }\end{array}$ & $\mathrm{C} 4$ & 4.31 & 0.844 & 0.747 & & \\
\hline & $\begin{array}{l}\text { I like the ability to use music } \\
\text { streaming services to listen to } \\
\text { whatever I want (Podcast, music, } \\
\text { and radio) from anywhere. }\end{array}$ & $\mathrm{C} 5$ & 4.21 & 0.915 & 0.764 & & \\
\hline \multirow{3}{*}{ Design } & $\begin{array}{l}\text { The music streaming services' user } \\
\text { interface is attractive. }\end{array}$ & D1 & 3.97 & 0.883 & 0.806 & \multirow{3}{*}{0.837} & \multirow{3}{*}{0.632} \\
\hline & $\begin{array}{l}\text { The music streaming service's user } \\
\text { interface is professionally designed. }\end{array}$ & $\mathrm{D} 2$ & 4.06 & 0.838 & 0.772 & & \\
\hline & $\begin{array}{l}\text { The overall look and feel of the } \\
\text { music streaming services' user } \\
\text { interface are visually appealing. }\end{array}$ & D3 & 3.95 & 0.847 & 0.806 & & \\
\hline \multirow{3}{*}{$\begin{array}{l}\text { Positive } \\
\text { Emotion }\end{array}$} & $\begin{array}{l}\text { Joy (joyful, pleased, romantic, } \\
\text { welcoming) }\end{array}$ & E1 & 3.96 & 0.806 & 0.745 & \multirow{3}{*}{0.886} & \multirow{3}{*}{0.659} \\
\hline & $\begin{array}{l}\text { Excitement (excited, thrilled, } \\
\text { enthusiastic) }\end{array}$ & $\mathrm{E} 2$ & 3.88 & 0.789 & 0.721 & & \\
\hline & $\begin{array}{l}\text { Peacefulness (comfortable, relaxed, } \\
\text { at rest) }\end{array}$ & E3 & 4.09 & 0.875 & 0.667 & & \\
\hline
\end{tabular}


Table 1 Descriptive Statistical Analysis of All Variables and Reliability Check (con.)

\begin{tabular}{|c|c|c|c|c|c|c|c|}
\hline \multirow{4}{*}{$\begin{array}{l}\text { Negative } \\
\text { Emotion }\end{array}$} & Anger (angry, irritated) & E5 & 3.98 & 1.050 & 0.808 & & \\
\hline & $\begin{array}{l}\text { Distress (frustrated, disappointed, } \\
\text { upset, downheartedness) }\end{array}$ & E6 & 4.01 & 1.103 & 0.828 & & \\
\hline & Disgust (disgusted, displeased, bad) & E7 & 4.34 & 0.957 & 0.811 & & \\
\hline & $\begin{array}{l}\text { Fear (scared, panicky, unsafe, } \\
\text { tension) }\end{array}$ & E8 & 4.27 & 1.002 & 0.801 & & \\
\hline \multirow{3}{*}{$\begin{array}{l}\text { Consumer } \\
\text { Satisfaction }\end{array}$} & $\begin{array}{l}\text { I am satisfied with my decision to } \\
\text { use music streaming services. }\end{array}$ & CS1 & 4.13 & 0.820 & 0.859 & \multirow{3}{*}{0.851} & \multirow{3}{*}{0.656} \\
\hline & $\begin{array}{l}\text { My choice to use music streaming } \\
\text { services is a wise one. }\end{array}$ & CS2 & 3.95 & 0.846 & 0.772 & & \\
\hline & $\begin{array}{l}\text { My experience with using music } \\
\text { streaming services is satisfactory. }\end{array}$ & CS3 & 4.13 & 0.804 & 0.796 & & \\
\hline \multirow{4}{*}{$\begin{array}{l}\text { Purchase } \\
\text { Intention }\end{array}$} & $\begin{array}{l}\text { I plan to pay for the premium } \\
\text { version of music streaming services. }\end{array}$ & PI1 & 3.83 & 1.095 & 0.911 & \multirow{4}{*}{0.872} & \multirow{4}{*}{0.696} \\
\hline & $\begin{array}{l}\text { I consider paying for the premium } \\
\text { version of music streaming services. }\end{array}$ & $\mathrm{PI} 2$ & 3.67 & 1.097 & Deleted & & \\
\hline & $\begin{array}{l}\text { I expect to pay for the premium } \\
\text { version of music streaming services. }\end{array}$ & PI3 & 3.93 & 1.028 & 0.700 & & \\
\hline & $\begin{array}{l}\text { I would pay for premium version of } \\
\text { music streaming services. }\end{array}$ & $\mathrm{PI} 4$ & 3.77 & 1.115 & 0.877 & & \\
\hline
\end{tabular}

According to Ryu (2014), as long as the CR of a constructed item is higher than 0.6, the AVE below 0.50 but higher than 0.40 can still be accepted. In this case, the CR of the Positive Emotion construct is 0.787 , which meets the criteria. Overall, the result of the CFA produces a good model fit where all the indicators meet the criteria $\left(x^{2}(341)=\right.$ 953.436, $x^{2} / \mathrm{df}=2.796, \mathrm{p}<0.001, \mathrm{GFI}=0.937, \mathrm{AGFI}=0.920, \mathrm{NFI}=0.937, \mathrm{CFI}=0.958$, RMSEA $=0.042$ ). The CFA and SEM methods had been used in previous studies where a similar theoretical framework as this study was applied, such as Jang and Namkung (2009), Lee and Yun (2015), Namkung and Jang (2010), and so on. As shown in Tables 3, most indices 'results meet the Fornell and Larcker criteria except for $x^{2} / \mathrm{df}$ (6.166). According to Hair et al. (2014), such as in this case, the CMIN/df cannot be used as the measurement of model fit in a study with a sample size larger than 750 . Therefore, we can safely assume that the model fit based on the SEM result is good and meets the criteria. 
Contemporary Management Research 175

Table 2 Discriminant Validity through the Square Root of AVE

\begin{tabular}{|c|c|c|c|c|c|c|c|c|c|}
\hline & CS & P & PQ & F & C & D & PE & NE & PI \\
\hline CS & $\mathbf{0 . 8 1 0}$ & & & & & & & & \\
\hline P & 0.613 & $\mathbf{0 . 7 3 6}$ & & & & & & & \\
\hline CQ & 0.541 & 0.250 & $\mathbf{0 . 7 7 1}$ & & & & & & \\
\hline F & 0.630 & 0.429 & 0.421 & $\mathbf{0 . 7 4 5}$ & & & & & \\
\hline C & 0.618 & 0.421 & 0.484 & 0.734 & $\mathbf{0 . 7 6 3}$ & & & & \\
\hline D & 0.510 & 0.285 & 0.411 & 0.490 & 0.398 & $\mathbf{0 . 7 9 5}$ & & & \\
\hline PE & 0.665 & 0.388 & 0.519 & 0.610 & 0.558 & 0.578 & $\mathbf{0 . 6 9 3}$ & & \\
\hline NE & 0.156 & 0.146 & 0.091 & 0.262 & 0.170 & 0.085 & 0.127 & $\mathbf{0 . 8 1 2}$ & \\
\hline PI & 0.679 & 0.590 & 0.317 & 0.403 & 0.436 & 0.312 & 0.424 & 0.098 & $\mathbf{0 . 8 3 4}$ \\
\hline
\end{tabular}

Table 3 Goodness-of-Fit of Model Measurement (SEM)

\section{Fit Index}

Chi-Square

2232.151

Degree of Freedom (d.f.)

Chi-Square / d.f.

6.166

GFI

0.848

AGFI

0.817

NFI

0.851

CFI

0.872

RMSEA

0.072

\section{CONCLUSION}

\section{Discussions}

The objectives of this study are to understand consumer behavior in the music streaming industry. This study was designed based on the theory of stimulus-organismresponse proposed by Mehrabian and Russell (1974) to explain how the consumer 
perceives music streaming attributes and their effect on consumption emotion and how it influences consumer satisfaction and purchase intention. This study shows that all the product attributes have a positive influence on positive emotion, which leads to consumer satisfaction and purchase intention. Among all the product attributes, consumers of music streaming services in Indonesia perceived "design" as the most favorite attribute of music streaming services. This finding can also be evidenced by the case study of Spotify, which is currently the biggest music streaming company in the industry. According to the case study, even though Spotify is not the first company to apply the "freemium" business model in the music streaming industry, it can dominate the market due to the advantage of its user interface. The user interface of Spotify is perceived as simpler and faster compared to its competitors.

Namkung and Jang (2010) explained that positive emotion could be a better predictor of behavioral intention than negative emotions. In contrast, this study found that most product attributes of music streaming can only be predicted by positive emotion, except for the functionality variable that can be predicted by both positive and negative emotions. This anomaly contradicts previous studies and can be considered a new finding in music literature. Therefore, the significance of the "functionality variable" should be recognized. Since most of the product attributes applied in this study could not be predicted by negative emotion, Namkung and Jang (2010) explained that positive emotion could be a better indicator to predict consumer behavior than negative emotion, especially in the service industry context. Namkung and Jang (2010) further explained that the measurement of emotion developed in psychology studies could be useful in the same field but will face some problems when it is applied in other fields, such as in consumer behavior studies. They also mentioned that negative emotion measurement could be useful if it is applied in a study where service failure often happened. Since positive emotion plays an important role in affecting consumer satisfaction, music streaming media companies are advised to maintain and improve all factors that will trigger the positive emotion of consumers, especially during the consumption process. Finally, this study also shows that purchase intention can only be predicted by consumer satisfaction, not consumption emotion. It indicates that consumer purchase intention cannot be predicted directly by consumption emotion but must be mediated by consumer satisfaction. It can also be explained that when consumers experience a positive emotion during the consumption process, they will feel satisfied with the service and will more likely want to pay for the subscription fee. 


\section{Theoretical Implications}

Contrary to the study (Namkung \& Jang, 2010), this study found that the functionality attributes can be predicted by both positive and negative emotions. This finding is considered as a new finding in music literature since previous studies found that only positive emotion can be used to predict consumer behavior. Future studies are expected to investigate this unique phenomenon. Among product attributes proposed by this study, "design" is perceived as the most important attribute of music streaming services. Consumers of music streaming services perceived the user interface of music streaming APP as attractive, professional, and visually appealing. This finding hopefully can be used as a reference for future studies about the role of the user interface of music streaming services to influence consumer behavior. Finally, this study shows that the "consumption emotion" applied faces some difficulty in capturing the mind of consumers during the consumption process. This is proven by the finding of this study, showing that most negative emotions failed to predict consumer behavior. Future studies may apply a better set of emotions to capture the emotions of consumers during the consumption process.

\section{Practical Implications}

Due to the increasing trend of music streaming services in the industry, the results of this study could be beneficial to both industry and academics alike. For companies, the results of this study can be used as recommendations for service improvements, especially to those who want to penetrate the Southeast Asian market or to those who seek to develop their own business, specifically in Indonesia. Hopefully, this study can be used as a reference or review of music literature relating to the music streaming industry for academics. This study's finding could help companies understand how each stimulus, such as competitive prices, content quality, functionalities, conveniences, and design of the music streaming services, can trigger positive emotion in consumers who may result in consumer satisfaction and purchase intention. This study also suggests that companies improve their music streaming app user interface. It promotes the idea that the music streaming app design is the most important attribute of music streaming services. Companies are expected to develop an intuitive user interface, specifically for smartphones, since the convenience and the functionality are also part of the music streaming advantages where a lot of users can take advantage of using music services. 


\section{Limitations and Directions for Future Research}

Firstly, there is the gender distribution of the sampling in the present study, where the participants are dominated by males (99.3\%). This phenomenon caused the underrepresentation of females in the study. The best explanation for this phenomenon is that the present study took place in the audio enthusiast community of Indonesia. As Keightley (1996) explained, the trend of High-audio devices in the post-World War 2 era is dominated by males, and it is perceived as the hobby of masculinity. Furthermore, women are perceived as only interested in the aesthetical appeal aspect rather than in the technology of the High-audio devices (Jansson, 2011). Since men pay more attention to the technology aspect of high-audio devices and to the quality of the audio generated by those devices, the audio enthusiast community nowadays is being dominated by males. It is suggested that the future study target a broader and more general segment of consumers in the music streaming industry to avoid this kind of problem.

Secondly, is that this study did not differentiate the brand of music streaming services. This study assumed that all music streaming service providers are the same in general features. In contrast, every music streaming service provider has its unique characteristics and market segmentation. A more specific brand of music streaming study might have a different result than those in this study.

Thirdly is that the present study did not differentiate between free and premium users. Similar to the previous limitation, the present study generalized all the respondents as having similar music streaming consumption experiences. In fact, the services offered by music streaming service providers are differentiated between premium users and free users. A study of music streaming services specifically addresses the premium users, or the free users might have different results.

Fourthly, this study finds that the most important attribute of music streaming services is design. Even though the findings of this study show that design is perceived as the most important attribute of music streaming services, this result cannot be generalized to all types of consumers. Each consumer has different preferences and different problems to face. For example, price is probably perceived as the most important attribute of music streaming services by students but not by entrepreneurs or full-time employees since the latter groups face fewer difficulties relating to monetary issues. Therefore, no product can satisfy all types of consumers with all dimensions, and each product has its own strength in one specific dimension or another to satisfy consumers. Future studies also suggested adding disposable income as the control variable to get a more detailed perspective on this issue. 
Finally, purchase intention was being used in this study to capture consumer behavior in the music streaming industry. Purchase intention is often applied in the literature to capture consumer behavior regarding purchase. In the context of this study, consumers probably plan to become premium users of music streaming services, but it does not mean they will do it immediately or in a shorter time.

\section{REFERENCES}

Aguiar, L. (2017). Let the music play? Free streaming and its effects on digital music consumption. Information Economics and Policy, 41, 1-14. https://doi.org/10.1016/j.infoecopol.2017.06.002

Ajzen, I. (2020). The theory of planned behavior: Frequently asked questions. Human Behavior and Emerging Technologies, 4(2), 314-324. https://doi:10.1002/hbe2.195.

Ajzen, I., \& Fishbein, M. (1980). Understanding attitudes and predicting social behavior. Prentice-Hall.

Alalwan, A. A., Dwivedi, Y. K., \& Rana, N. P. (2017). Factors influencing adoption of mobile banking by Jordanian bank customers: Extending UTAUT2 with trust. International Journal of Information Management, 37(3), 99-110. https://doi.org/10.1016/j.ijinfomgt.2017.01.002

Alexander, B., \& Cano, M. B. (2019). Futurising the physical store in the omnichannel retail environment. In Piotrowicz, W., \& Cuthbertson, R. (Eds.) Exploring Omnichannel Retailing (pp.197-223). Springer, Cham. https://doi:10.1007/978-3319-98273-1_9

Anderson, R. E. (1973). Consumer dissatisfaction: The effect of disconfirmed expectancy on perceived product performance. Journal of Marketing Research, 10(1), 38-44. https://doi.org/10.2307/3149407

Annaraud, K., \& Berezina, K. (2020). Predicting satisfaction and intentions to use online food delivery: What really makes a difference? Journal of Foodservice Business Research, 23(4), 305-323. https://doi.org/10.1080/15378020.2020.1768039

Arora, R. (1982). Validation of an S-O-R model for situation, enduring, and response components of involvement. Journal of Marketing Research, 19(4), 505-516. https://doi.org/10.2307/3151723.

Austin, W., McGinn, N. C., \& Susmilch, C. (1980). Internal standards revisited: Effects of social comparisons and expectancies on judgments of fairness and satisfaction. 
Contemporary Management Research 180

Journal of Experimental Social Psychology, 16(5), 426-441.

https://doi.org/10.1016/0022-1031(80)90049-9

Babin, B. J., Darden, W. R., \& Babin, L. A. (1998). Negative emotions in marketing research: Affect or artifact? Journal of Business Research, 42(3), 271-285. https://doi.org/10.1016/S0148-2963(97)00124-0

Bagozzi, R. P. (1986). Principles of marketing management. Chicago: Science Research Associates, 32(3).

Bagozzi, R. P., Gopinath, M., \& Nyer, P. U. (1999). The role of emotions in marketing. Journal of the Academy of Marketing Science, 27(2), 184-206. https://doi.org/10.1177/0092070399272005

Bai, B., Law, R., \& Wen, I. (2008). The impact of website quality on customer satisfaction and purchase intentions: Evidence from Chinese online visitors. International Journal of Hospitality Management, 27(3), 391-402. https://doi.org/10.1016/j.ijhm.2007.10.008

Barsky, J., \& Nash, L. (2002). Evoking emotion: Affective keys to hotel loyalty. Cornell Hotel and Restaurant Administration Quarterly, 43(1), 39-46. https://doi.org/10.1016/s0010-8804(02)80007-6

Bearden, W. O., \& Teel, J. E. (1983). Selected determinants of consumer satisfaction and complaint reports. Journal of Marketing Research, 20(1), 21-28. https://doi.org/10.1177/002224378302000103

Belk, R. (2015). Consumer Behavior. In D. T. Cook, \& J. M. Ryan, (Eds). The Wiley Blackwell encyclopedia of consumption and consumer studies, 1-6. https://doi:10.1002/9781118989463.wbeccs052

Bhattacherjee, A. (2001). An empirical analysis of the antecedents of electronic commerce service continuance. Decision Support Systems, 32(2), 201-214. https:/doi.org/10.1016/S0167-9236(01)00111-7

Bilgili, B., \& Ozkul, E. (2015). Brand awareness, brand personality, brand loyalty and consumer satisfaction relations in brand positioning strategies (a Torku brand sample). Journal of Global Strategic Management, 2(9), 89-89. https://doi:10.20460/jgsm.2015915576

Bloch, P. H. (1995). Seeking the ideal form: Product design and consumer response. Journal of Marketing, 59(3), 16-29. https://doi.org/10.2307/1252116

Bradburn, N. M. (1969). The structure of psychological well-being. Aldine.

Carlson, J., Rahman, M., Voola, R., \& De Vries, N. (2018). Customer engagement behaviours in social media: Capturing innovation opportunities. Journal of Services Marketing, 32(1), 83-94. https://doi.org/10.1108/JSM-02-2017-0059 
Chang, H. J., \& Jai, T.-M. (2015). Is fast fashion sustainable? The effect of positioning strategies on consumers' attitudes and purchase intentions. Social Responsibility Journal, 11(4), 853-867. https://doi.org/10.1108/srj-07-2014-0095

Chang, H.-J., Eckman, M., \& Yan, R.-N. (2011). Application of the Stimulus-OrganismResponse model to the retail environment: The role of hedonic motivation in impulse buying behavior. The International Review of Retail, Distribution and Consumer Research, 21(3), 233-249.

https://doi.org/10.1080/09593969.2011.578798

Chitturi, R., Raghunathan, R., \& Mahajan, V. (2007). Form versus function: How the intensities of specific emotions evoked in functional versus hedonic trade-offs mediate product preferences. Journal of Marketing Research, 44(4), 702-714. https://doi.org/10.1509/jmkr.44.4.702

Cho, W.-C., Lee, K. Y., \& Yang, S.-B. (2018). What makes you feel attached to smartwatches? The stimulus-organism-response (S-O-R) perspectives. Information Technology \& People, 32(2), 319-343. https://doi.org/10.1108/itp-052017-0152

Churchill Jr, G. A., \& Suprenant, C. (1982). An investigation into the determinants of customer satisfaction. Journal of marketing research. 19(4), 491-504. https://doi.org/10.1177/002224378201900410

Darwin, C. (1979). The expression of emotions in man and animals. St. Martin's Press. https://doi.org/10.1017/cbo9780511694110.017

de Hooge, I. E. (2014). Predicting consumer behavior with two emotion appraisal dimensions: Emotion valence and agency in gift giving. International Journal of Research in Marketing, 31(4), 380-394. https://doi:10.1016/j.ijresmar.2014.04.002.

Demangeot, C., \& Broderick, A. J. (2010). Consumer perceptions of online shopping environments: A gestalt approach. Psychology \& Marketing, 27(2), 117-140. https://doi:10.1002/mar.20323

Deng, L., \& Poole, M. S. (2010). Affect in web interfaces: A study of the impacts of web page visual complexity and order. MIS Quarterly, 34(4), 711-730. https://doi.org/10.2307/25750702

Doerr, J., Benlian, A., Vetter, J., \& Hess, T. (2010). Pricing of content services-an empirical investigation of music as a service. In Sustainable e-Business Management (pp. 13-24). Springer. https://doi.org/10.1007/978-3-642-15141-5_2 
Evanschitzky, H., Iyer, G. R., Hesse, J., \& Ahlert, D. (2004). E-satisfaction: A reexamination. Journal of Retailing, 80(3), 239-247. https://doi.org/10.1016/j.jretai.2004.08.002

Fiore, A. M., \& Kim, J. (2007). An integrative framework capturing experiential and utilitarian shopping experience. International Journal of Retail \& Distribution Management, 35(6), 421-442. https://doi.org/10.1108/09590550710750313

Flores, J., \& Vasquez-Parraga, A. Z. (2015). The impact of choice on co-produced customer value creation and satisfaction. Journal of Consumer Marketing, 32(1), 15-25. https://doi:10.1108/jcm-04-2014-0931

Francioni, B., Savelli, E., \& Cioppi, M. (2018). Store satisfaction and store loyalty: The moderating role of store atmosphere. Journal of Retailing and Consumer Services, 43, 333-341. http://doi:10.1016/j.jretconser.2018.05.005

Gan, C., \& Wang, W. (2017). The influence of perceived value on purchase intention in social commerce context. Internet Research, 27(4), 772-785. https://doi.org/10.1108/intr-06-2016-0164

Grace, D., Ross, M., \& Shao, W. (2015). Examining the relationship between social media characteristics and psychological dispositions. European Journal of Marketing, 49(9/10), 1366-1390. https://doi.org/10.1108/ejm-06-2014-0347

Ha, Y., \& Lennon, S. J. (2010). Effects of site design on consumer emotions: role of product involvement. Journal of Research in Interactive Marketing, 4(2), 80-96. https://doi.org/10.1108/17505931011051641

Hair, J. F., Black, W. C., Babin, B. J., \& Anderson, R. E. (2014). Multivariate data analysis. Pearson

Han, H., \& Back, K.-J. (2007). Investigating the effects of consumption emotions on customer satisfaction and repeat visit intentions in the lodging industry. Journal of Hospitality \& Leisure Marketing, 15(3), 5-30. https://doi.org/10.1300/j150v15n03_02

Hassenzahl, M., \& Tractinsky, N. (2006). User experience-a research agenda. Behaviour \& Information Technology, 25(2), 91-97. https://doi.org/10.1080/01449290500330331

Herrera, C. F., \& Blanco, C. F. (2011). Consequences of consumer trust in PDO food products: The role of familiarity. Journal of Product \& Brand Management, 20(4), 282-296. https://doi:10.1108/10610421111148306

Hsu, C.-L., \& Lin, J. C.-C. (2016). Effect of perceived value and social influences on mobile app stickiness and in-app purchase intention. Technological Forecasting and Social Change, 108, 42-53. https://doi.org/10.1016/j.techfore.2016.04.012 
Hsu, C.-L., Chang, K.-C., \& Chen, M.-C. (2012). The impact of website quality on customer satisfaction and purchase intention: perceived playfulness and perceived flow as mediators. Information Systems and E-Business Management, 10(4), 549570. https://doi.org/10.1007/s10257-011-0181-5

Hui, M. K., \& Tse, D. K. (1996). What to tell consumers in waits of different lengths: An integrative model of service evaluation. Journal of Marketing, 60(2), 81-90. https://doi.org/10.1177/002224299606000206

Islam, J. U., \& Rahman, Z. (2017). The impact of online brand community characteristics on customer engagement: An application of Stimulus-Organism-Response paradigm. Telematics and Informatics, 34(4), 96-109. https://doi.org/10.1016/j.tele.2017.01.004

Izard, C. E. (1977). Human emotions. Plenum Press. https://doi.org/10.1007/978-1-48992209-0

Jacoby, J. (2002). Stimulus-organism-response reconsidered: An evolutionary step in modeling (consumer) behavior. Journal of Consumer Psychology, 12(1), 51-57. https://doi.org/10.1207/S15327663JCP1201_05

Jang, S. S., \& Namkung, Y. (2009). Perceived quality, emotions, and behavioral intentions: Application of an extended Mehrabian-Russell model to restaurants. Journal of Business Research, 62(4), 451-460. https://doi.org/10.1016/j.jbusres.2008.01.038

Jansson, S. (2011). "Listen to these Speakers": Swedish hi-fi enthusiasts, gender, and listening. IASPM@ Journal, 1(1), 1-11. https://doi.org/10.5429/20793871(2010)v1i2.5en

Jennings, P. A., Brown, J. L., Frank, J. L., Doyle, S., Oh, Y., Davis, R., Rasheed, D., DeWeese, A., DeMauro, A. A. Cham, H., \& Greenberg, M. T. (2017). Impacts of the CARE for teachers program on teachers 'social and emotional competence and classroom interactions. Journal of Educational Psychology, 109(7), 1010-1028. https://doi:10.1037/edu0000187

Jiang, Z., Chan, J., Tan, B. C., \& Chua, W. S. (2010). Effects of interactivity on website involvement and purchase intention. Journal of the Association for Information Systems, 11(1), Article 1. https://doi.org/10.17705/1jais.00218

Jörling, M., Böhm, R., \& Paluch, S. (2020). Mechanisms and consequences of anthropomorphizing autonomous products. Schmalenbach Business Review, 72, 485-510. https://doi.org/10.1007/s41464-020-00100-3 
Keightley, K. (1996). 'Turn it down!'she shrieked: gender, domestic space, and high fidelity, 1948-59 1. Popular Music, 15(2), 149-177. https://doi.org/10.1017/s0261143000008096

Keightley, K. (2010). Taking Popular Music (and Tin Pan Alley and Jazz) Seriously. Journal of Popular Music Studies, 22(1), 90-97. https://doi:10.1111/j.15331598.2010.01223.x

Kim, J., \& Lennon, S. J. (2013). Effects of reputation and website quality on online consumers' emotion, perceived risk and purchase intention: Based on the stimulus-organism-response model. Journal of Research in Interactive Marketing, 7(1), 33-56. https://doi.org/10.1108/17505931311316734

Kim, J., Nam, C., \& Ryu, M. H. (2017). What do consumers prefer for music streaming services?: A comparative study between Korea and US. Telecommunications Policy, 41(4), 263-272. https://doi.org/10.1016/j.telpol.2017.01.008

Kim, J., Yang, K. Y., \& Kim, B. Y. (2013). Online retailer reputation and consumer response: examining cross cultural differences. International Journal of Retail \& Distribution Management, 41(9), 688-705. https://doi.org/10.1108/ijrdm-02-20120009

Kim, S. K., Chen, R. P., \& Zhang, K. (2016). Anthropomorphized helpers undermine autonomy and enjoyment in computer games. Journal of Consumer Research, 43(2), 282-302. https://doi:10.1093/jcr/ucw016

Lee, H.-J., \& Yun, Z.-S. (2015). Consumers' perceptions of organic food attributes and cognitive and affective attitudes as determinants of their purchase intentions toward organic food. Food Quality and Preference, 39, 259-267. https://doi.org/10.1016/j.foodqual.2014.06.002

Lee, J. (2014). Visitors' emotional responses to the festival environment. Journal of Travel \& Tourism Marketing, 31(1), 114-131. https://doi.org/10.1080/10548408.2014.861726

Lee, S., Ha, S., \& Widdows, R. (2011). Consumer responses to high-technology products: Product attributes, cognition, and emotions. Journal of Business Research, 64(11), 1195-1200. https://doi.org/10.1016/j.jbusres.2011.06.022

Lemon, K. N., \& Verhoef, P. C. (2016). Understanding customer experience throughout the customer journey. Journal of Marketing, 80(6), 69-96. https://doi.org/10.1509/jm.15.0420

Li, Y.-M., \& Yeh, Y.-S. (2010). Increasing trust in mobile commerce through design aesthetics. Computers in Human Behavior, 26(4), 673-684. https://doi.org/10.1016/j.chb.2010.01.004 
Malik, S. U. (2012). Customer satisfaction, perceived service quality and mediating role of perceived value. International Journal of Marketing Studies, 4(1). http://doi:10.5539/ijms.v4n1p68

Mehrabian, A., \& Russell, J. A. (1974). An approach to environmental psychology. the MIT Press.

Mehrabian, A., \& Wixen, W. J. (1986). Preferences for individual video games as a function of their emoitional effect on players. Journal of applied Social Psychology, 16(1), 3-15. https://doi.org/10.1111/j.1559-1816.1986.tb02274.x

Meyers-Levy, J., \& Tybout, A. M. (1989). Schema congruity as a basis for product evaluation. Journal of consumer research, 16(1), 39-54. https://doi.org/10.1086/209192

Morimura, F., Nishioka, K., \& Minami, C. (2014). Waiting in checkout lines: how selfcheckout systems affect customers' perceptions of waiting and satisfaction. Global Marketing Conference, Singapore. https://doi:10.15444/gmc2014.11.03.03

Nah, F. F. H., Eschenbrenner, B., \& DeWester, D. (2011). Enhancing brand equity through flow and telepresence: A comparison of 2D and 3D virtual worlds. MIS Quarterly, 35(3), 731-747. https://doi.org/10.2307/23042806

Namkung, Y., \& Jang, S. C. (2010). Effects of perceived service fairness on emotions, and behavioral intentions in restaurants. European Journal of Marketing, 44(9/10), 1233-1259. https://doi.org/10.1108/03090561011062826

Oyedele, A., \& Simpson, P. M. (2018). Streaming apps: What consumers value. Journal of Retailing and Consumer Services, 41, 296-304.

Park, K., Kwak, C., Lee, J., \& Ahn, J.-H. (2018). The effect of platform characteristics on the adoption of smart speakers: Empirical evidence in South Korea. Telematics and Informatics, 35(8), 2118-2132.

Patanasiri, A., \& Krairit, D. (2019). A comparative study of consumers' purchase intention on different internet platforms. Mobile Networks and Applications, 24(1), 145-159. https://doi.org/10.1007/s11036-018-1139-3

Pavlou, P. A. (2003). Consumer acceptance of electronic commerce: Integrating trust and risk with the technology acceptance model. International Journal of Electronic Commerce, 7(3), 101-134. https://doi.org/10.1080/10864415.2003.11044275

Reynoso, J. (2010). Satisfaction: A behavioral perspective on the consumer. Journal of Service Management, 21(4), 549-551. https://doi:10.1108/09564231011066132 
Richins, M. L. (2013). When wanting is better than having: Materialism, transformation expectations, and product-evoked emotions in the purchase process. Journal of Consumer Research, 40(1), 1-18. https://doi:10.1086/669256

Rose, C. (2013). Maternal consumption: A view from the past. Journal of Consumer Culture, 13(2), 178-198. https://doi:10.1177/1469540513480164

Royce, J. R. (1963). Factors as theoretical constructs. American Psychologist, 18(8), 522528. https://doi.org/10.1037/h0044493.

Ryu, E. (2014). The role of centering for interaction of level 1 variables in multilevel structural equation models. Structural Equation Modeling: A Multidisciplinary Journal, 22(4), 617-630. https://doi:10.1080/10705511.2014.936491

Sabiote Ortiz, C. M., Frías-Jamilena, D. M., \& Castaneda Garcia, J. A. (2017). Overall perceived value of a tourism service: Analysing the spillover effect between electronic channel and consumption of the hotel service. Tourism and Hospitality Research, 17(2), 217-227. https://doi.org/10.1177/1467358415613410

Salisbury, W. D., Pearson, R. A., Pearson, A. W., \& Miller, D. W. (2001). Perceived security and World Wide Web purchase intention. Industrial Management \& Data Systems, 101(4), 165-177. https://doi.org/10.1108/02635570110390071

Shulley, L. J., \& Shake, M. C. (2016). Investigating the relationship between bilingualism, cognitive control, and mind wandering. Journal of Cognitive Psychology, 28(3), 257-274. https://doi:10.1080/20445911.2015.1128438

Srivastava, M., \& Rai, A. K. (2013). An investigation of mediating and moderating variables in service quality - customer loyalty relationship. International Journal of Customer Relationship Marketing and Management, 4(3), 20-43. https://doi:10.4018/jcrmm.2013070102

Taylor, S. A., \& Baker, T. L. (1994). An assessment of the relationship between service quality and customer satisfaction in the formation of consumers' purchase intentions. Journal of retailing, 70(2), 163-178.

Thang, D. C. L., \& Tan, B. L. B. (2003). Linking consumer perception to preference of retail stores: an empirical assessment of the multi-attributes of store image. Journal of Retailing and Consumer Services, 10(4), 193-200. https://doi.org/10.1016/s0969-6989(02)00006-1

Troiville, J., Hair, J. F., \& Cliquet, G. (2019). Definition, conceptualization and measurement of consumer-based retailer brand equity. Journal of Retailing and Consumer Services, 50, 73-84. https://doi.org/10.1016/j.jretconser.2019.04.022 
Vinish, P., Pinto, P., Hawaldar, I. T., \& Pinto, S. (2020). Impulse buying behavior among female shoppers: Exploring the effects of selected store environment elements. Innovative Marketing, 16(2), 54-70. https://doi:10.21511/im.16(2).2020.05.

Wagner, T. M., Benlian, A., \& Hess, T. (2014). Converting freemium customers from free to premium-The role of the perceived premium fit in the case of music as a service. Electronic Markets, 24(4), 259-268. https://doi.org/10.1007/s12525-0140168-4

Watkins, R., \& Molesworth, M. (2012). Attachment to digital virtual possessions in videogames. In R.W. Belk, S. Askegaard, \& L. Scott, (Eds.), Research in Consumer Behavior (Vol. 14, pp.153-170), Emerald Group Publishing Limited, Bingley, https://doi:10.1108/s0885-2111(2012)0000014012

Westbrook, R. A., \& Oliver, R. L. (1991). The dimensionality of consumption emotion patterns and consumer satisfaction. Journal of Consumer Research, 18(1), 84-91. https://doi.org/10.1086/209243

White, W. F. (1993). From SR to SOR: What every teacher should know. Education, $113(4), 620-630$.

Wlömert, N., \& Papies, D. (2016). On-demand streaming services and music industry revenues - Insights from Spotify's market entry. International Journal of Research in Marketing, 33(2), 314-327. https://doi.org/10.1016/j.ijresmar.2015.11.002

Wong, A. (2020). Consumer perceptions of service convenience in hedonic and utilitarian retail settings in China. Journal of International Consumer Marketing, 1-19. https://doi:10.1080/08961530.2020.1816866

Wong, E., Rasoolimanesh, S. M., \& Sharif, S. P. (2020). Using online travel agent platforms to determine factors influencing hotel guest satisfaction. Journal of Hospitality and Tourism Technology. 11(3), 425-445. https://doi.org/10.1108/jhtt07-2019-0099

Woodworth, R. S., \& Schlosberg, H. (1954). Experimental psychology. Oxford and IBH Publishing.

Wu, C.-S., Cheng, F.-F., \& Yen, D. C. (2008). The atmospheric factors of online storefront environment design: An empirical experiment in Taiwan. Information \& Management, 45(7), 493-498. https://doi.org/10.1016/j.im.2008.07.004

Wu, W.-Y., Lee, C.-L., Fu, C.-S., \& Wang, H.-C. (2013). How can online store layout design and atmosphere influence consumer shopping intention on a website? 
Contemporary Management Research 188

International Journal of Retail \& Distribution Management, 42(1), 4-24. https://doi.org/10.1108/ijrdm-01-2013-0035.

Yang, H., \& Lee, H. (2018). Exploring user acceptance of streaming media devices: an extended perspective of flow theory. Information Systems and E-Business Management, 16(1), 1-27. https://doi.org/10.1007/s10257-017-0339-x

Yoo, J., \& Kim, M. (2014). The effects of home page design on consumer responses: Moderating role of centrality of visual product aesthetics. Computers in Human Behavior, 38(Sep.), 240-247. http://doi:10.1016/j.chb.2014.05.030

Zhang, H., Lu, Y., Gupta, S., \& Gao, P. (2015). Understanding group-buying websites continuance: An extension of expectation confirmation model. Internet Research, 25(5), 767-793. https://doi.org/10.1108/intr-05-2014-0127

Zhu, M., Billeter, D. M., \& Inman, J. J. (2012). The double-edged sword of signaling effectiveness: When salient cues curb post-purchase consumption. Journal of Marketing Research, 49(1), 26-38. https://doi:10.1509/jmr.09.0531.

Dr. Chiehwen Ed Hsu is currently a professor at Institute of International Management, National Cheng Kung University, Taiwan. His current research interests include Health Disparity Research, Health Management, Strategic Management, Management and Policy. He has published many articles in recent years.

Mr. Yeshwant S. Raj (Corresponding author) was an assistant professor for five years in India, possessing two master's degrees, one in Industrial engineering and another in MBA. He is currently a Ph.D. Student at National Cheng Kung University. He has published more than 12 international journal articles and another seven under review. His research interests include supply chain management, Technology Management, Psychology in Employee behaviour, strategic, HRM, OB, marketing, and management science-related content.

Mr. Bob Sandy is a master's student at Institute of International Management, National Cheng Kung University, Taiwan. His research interest includes strategic management, consumer behavior, and marketing. 